\title{
Ultrastructure of paraspermatozoa of cerithiacean gastropods (Prosobranchia: Mesogastropoda)
}

\author{
John M. Healy* \\ Department of Zoology, University of Queensland; St. Lucia 4067, Brisbane, \\ Queensland, Australia
}

\begin{abstract}
Using transmission electron microscopy, paraspermatozoa of representative species of the families Cerithiidae, Potamididae, Planaxidae, Dialidae and the genus Australaba (family position uncertain) have been examined and compared with those produced by other prosobranchs, particularly other investigated cerithiaceans. Special attention is focused on the phylogenetic importance of paraspermatozoa and euspermatozoa within the superfamily Cerithiacea. The paraspermatozoa of cerithiacean gastropods fall into two structural categories: (1) those with a 'head' region and a 'tail tuft' (number of tails and the length of the tail tuft variable - Cerithiidae, Planaxidae, Potamididae, Modulidae, Turritellidae, Campanilidae, Pleuroceridae, Obtortio, Australaba); and (2) those with an elongate, vermiform body filled with large electron-dense vesicles and up to ninety axonemes - the latter emerging as numerous short tails from the posterior half of the paraspermatozoon body (Dialidae).
\end{abstract}

\section{INTRODUCTION}

Since the work of Siebold (1836), light microscopists and more recently researchers utilizing electron microscopy have examined and discussed the dimorphic (or polymorphic) spermatozoa of a wide variety of mesogastropod and neogastropod prosobranchs (for references see Healy \& Jamieson, 1981). In order to differentiate the two or sometimes more types of spermatozoa produced in any one species, various terms have been employed including 'typical sperm'/"atypical sperm', 'eupyrene sperm'/"oligopyrene sperm'/'apyrene sperm', and 'normal'/'abnormal sperm'. Healy \& Jamieson (1981) introduced the terms 'euspermatozoa' and 'paraspermatozoa' * as replacements for the unsatisfactory or inappropriate earlier terminology and both terms will be used throughout the present study.

\footnotetext{
- Present address: School of Biological Sciences (Zoology Building), University of Sydney; Sydney 2000, New South Wales, Australia

* The term 'paraspermatic cell', independently advanced by Melone et al. (1980) as a replacement for 'atypical sperm', was re-defined by Healy \& Jamieson (1981) to embrace both paraspermatozoa and also the nurse cells of Littorina (which form a spermatozeugma-like association with euspermatozoa). In this new sense, paraspermatozoa and nurse cells (Littorina) can be collectively referred to as paraspermatic cells.
} 
While there is no doubt that euspermatozoa ('typical', 'eupyrene' spermatozoa) are true fertilizing male gametes, much still remains to be learnt of the role of paraspermatozoa in mesogastropod and neogastropod reproduction. Of the functions that have been suggested for paraspermatozoa (in some cases with supporting cytological or cytochemical evidence), the most plausible seems one of maintenance of euspermatozoal viability or initiation of euspermatozoal motility through the eventual degeneration of paraspermatozoa (cf. Healy \& Jamieson, 1981 for a fuller discussion). In some, principally aphallic, groups of mesogastropods, euspermatozoa may be attached in large numbers to paraspermatozoa (to form spermatozeugmata) which may or may not be motile (see Ankel, 1958; Bulnheim, 1962, 1968; Nishiwaki, 1964; Nishiwaki \& Tochimoto, 1969; Robertson, 1983). Presumably, such associations assist in the transportation of euspermatozoa or at least in the prevention of premature dispersal of euspermatozoa.

Few authors have explored the usefulness of sperm dimorphism as a means of analysing the relationships between gastropod taxa. Nishiwaki (1964) examined the spermatozoa of many prosobranch gastropods using light microscopy ('primitive' sperm of archaeogastropods, dimorphic sperm of mesogastropods and neogastropods); he was the first worker to relate paraspermatozoal morphology to phylogeny of the Prosobranchia on a broad scale. At the level of the electron microscope, the systematic/phylogenetic value of sperm structure within the Prosobranchia becomes even more evident (see discussions in Giusti, 1971; Koike \& Nishiwaki, 1980; Melone et al., 1980; Healy, 1983a), especially in groups such as the Cerithiacea where sperm dimorphism is pronounced (cf. Healy, 1982, 1983 b; Healy \& Jamieson, 1981).

The purposes of this paper are firstly to examine the fine structure of paraspermatozoa from various families and genera of the Cerithiacea and secondly to correlate the differences and similarities observed with those that exist between euspermatozoa of cerithiacean family group and genus group taxa (Healy, 1983b).

\section{MATERIALS AND METHODS}

Mature specimens of each species used in this study were collected between 1979 and 1982 from the following localities: Lota, southern Queensland [Cerithidea largillierti Philippi, Cerithidea obtusa (Lamarck), Australaba sp.]; Sandgate, southern Queensland [Clypeomorus moniliferus (Kiener); Velacumantus australis (Quoy \& Gaimard)]; Low Isles, northern Queensland [Rhinoclavis vertagus (Linnaeus)], Cairns, northern Queensland [Telescopium telescopium (Linnaeus)], Yule Point, northern Queensland [Planaxis sulcatus (Born)], Pebbly Beach, northern Queensland [Clypeomorus breviculus (Sowerby)], Lizard Island, northern Queensland (Diala cento), Manukau Harbour, North Island, New Zealand [Zeacumantus subcarinatus (Sowerby); Zeacumantus lutulentus (Kiener)]. With the exception of Velacumantus australis, Clypeomorus breviculus and Zeacumantus lutulentus, results for all of the above listed species have been figured in this paper.

Sperm ducts (and gonad tissue) of Clypeomorus moniliferus, Clypeomorus breviculus, Cerithidea largillierti, Cerithidea obtusa, Velacumantus australis and Planaxis sulcatus were fixed in $2.5 \%, 0.1 \mathrm{M}$ phosphate-buffered glutaraldehyde for two h., rinsed in buffer and post-fixed in $1 \%$, phosphate-buffered osmium tetroxide solution for 
$80 \mathrm{~min}$. After rinsing and ethanol dehydration, tissues were gradually embedded in Spurr's medium. Tissues from Telescopium telescopium, Australaba sp., Rhinoclavis vertagus, Zeacumantus lutulentus and Zeacumantus subcarinatus were processed with sucrose added to glutaraldehyde, osmium tetroxide solution and buffer (to give a $5 \%$ sucrose concentration in each case). Tissues from Diala cento were taken from whole specimens (shell intact) fixed in alcoholic formalin (see Culling, 1974). Tissues of this species were osmicated, rinsed, dehydrated and embedded as per other species studied. Thin sections were cut using an LKB 4 Ultrotome, collected on 200 mesh copper grids, stained with uranyl acetate and lead citrate and examined under AEI 500 Corinth and Siemens Elmiskop I transmission electron microscopes.

Voucher specimens of all species examined have been lodged either with the Australian Museum (Sydney) or the Queensland Museum (Brisbane). Material lodged with the Australian Museum is as follows: Planaxis sulcatus C. 138054; Rhinoclavis vertagus C. 138055; Clypeomorus moniliferus C. 138057; Velacumantus australis C. 138058; Clypeomorus breviculus C. 138060; Telescopium telescopium C. 138061; Australaba sp. C. 138063, C. 138064; Cerithidea largillierti C. 138066, C. 138067; Cerithidea obtusa C. 138068, C. 138069; Diala cento C. 142545. The full specific name of the species of Australaba used in this study has not been determined. Material lodged with the Queensland Museum is as follows: Zeacumantus subcarinatus MO 15904; Zeacumantus lutulentus MO 15903.

\section{RESULTS}

Results obtained for Rhinoclavis vertagus, Clypeomorus moniliferus, Clypeomorus breviculus (all Cerithiidae); Zeacumantus subcarinatus, Zeacumantus lutulentus, Velacumantus australis (all Potamididae, subfamily Batillariinae), Planaxis sulcatus (Planaxidae) are described in this chapter. Results for Clypeomorus breviculus, Zeacumantus lutulentus and Velacumantus australis are not figured.

Paraspermatozoa of these species all have a short or moderately short head region (acrosome-like structure at apex, nuclear core surrounded by mosaic sheath, axonemes attached to base of nuclear core) followed by a midpiece (axonemes interspersed with elongate mitochondria) and tail tuft (emergent axonemes sheathed by plasma membrane and often glycogen granules).

\section{Rhinoclavis vertagus}

An acrosome-like structure forms the apex of the head of the Rhinoclavis vertagus paraspermatozoon, and is composed of a basally invaginated cone and a plug of dense material which lies within the cone invagination (Figs $1 \mathrm{~A}, \mathrm{~B}$ ). The bulk of the head consists of the condensed nuclear core surrounded by a mosaic sheath of tightly-packed, electron-dense blocks (Fig. 1C). Occasionally, spherical spaces are visible in the dense blocks (Figs 1 C,D). Their functional significance, if any, is unknown. Towards the apex of the head, the nuclear core sometimes shows nodular 'swellings' (Fig. 1C). These, conceivably, are the end result of localized pressure exerted by the blocks of the mosaic sheath on the condensing nuclear core during development. Longitudinal and transverse sections indicate that the six or eight axonemes present, do not penetrate more than 
John M. Healy
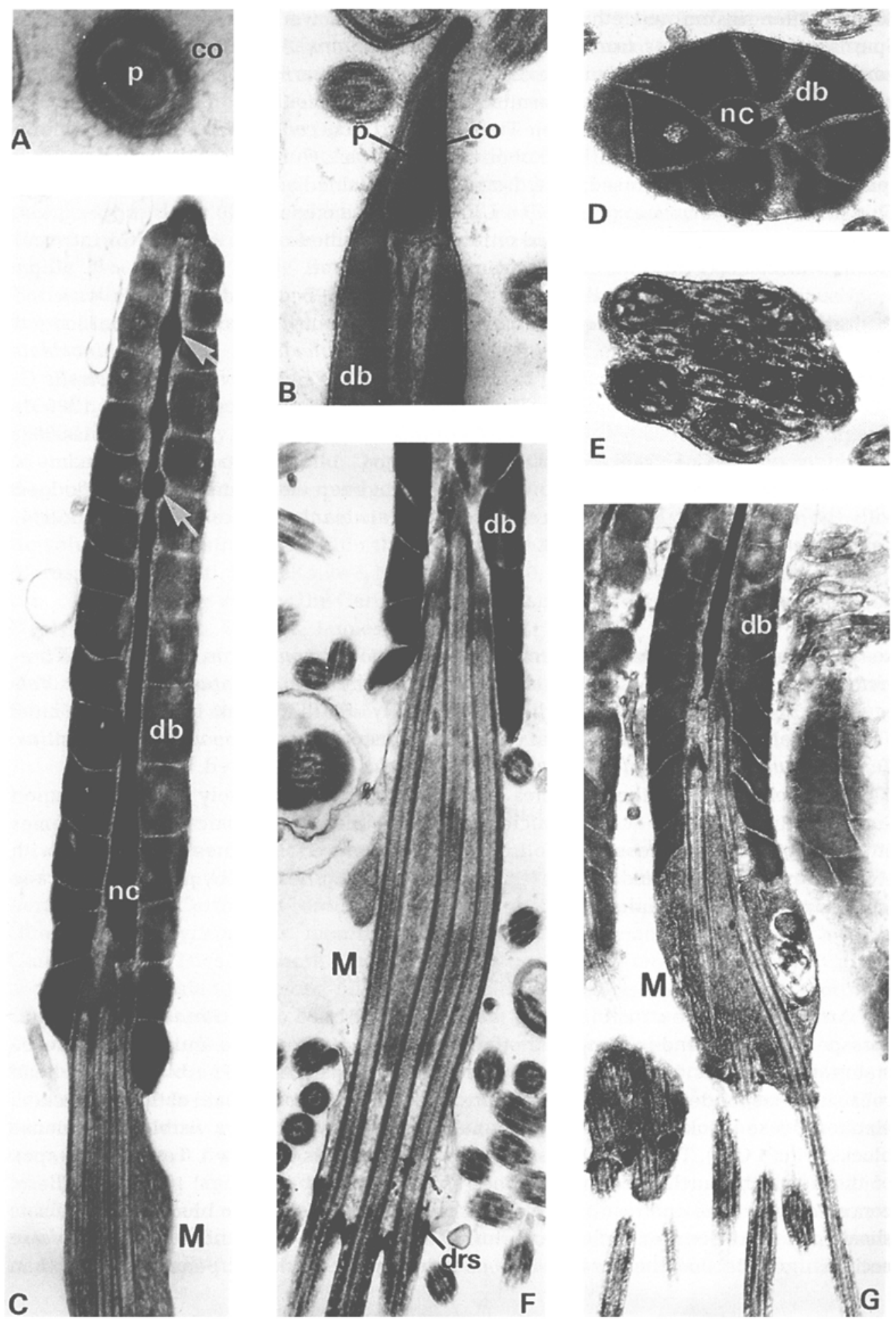
0.8-1 $\mu \mathrm{m}$ into the head region, and are attached via short, electron-dense rods to grooves in the base of the nuclear core (see Figs $1 C, F, G ; 2 A, B$ ). The head region is approximately $6-8 \mu \mathrm{m}$ in length.

Immediately behind the head, the multiple axonemes each become partly surrounded by elongate mitochondria to form, collectively, the midpiece (Figs $1 \mathrm{C}, E, F, G$ ). These mitochondria contain well-developed, randomly orientated cristae (Fig. 1E) and may penetrate slightly within the base of the head region (Figs $1 \mathrm{G} ; 2 \mathrm{~B}$ ). The midpiece is most commonly short (1-2 $\mu \mathrm{m}$, Fig. 1G), but on occasion may be appreciably longer (up to $5 \mu \mathrm{m}$, Fig. 1F). On emerging from the midpiece, each axoneme is enclosed by the plasma membrane and usually a sheath of dense glycogen granules the presence of these deposits appears to be a variable feature in Rhinoclavis paraspermatozoa - Figs $1 F, G$ ). A dense ring structure (attached to the inside surface of the plasma membrane) is associated with each tail at the point of emergence from the midpiece (see Figs 1 F,G).

\section{Clypeomorus moniliferus and C. breviculus}

Paraspermatozoa of Clypeomorus moniliferus and C. breviculus* closely resemble those of Rhinoclavis in almost all features. The head is 7 to $8 \mu \mathrm{m}$ in length and is composed of a nuclear core (tapered anteriorly), a mosaic sheath of dense blocks and a very well-developed acrosome-like structure (Figs $2 \mathrm{C}-\mathrm{H}$ ). Figures $2 \mathrm{D}, \mathrm{E}$ show that the plug of electron-dense material which forms part of the acrosome-like structure may vary in size. The five to seven axonemes attach to grooves in the base of the nuclear core (Figs $\left.2 F_{i} H\right)$. Beyond the head, the axonemes become associated with rod-shaped mitochondria (each containing irregularly orientated cristae) to form the midpiece (Figs $2 \mathrm{H}, \mathrm{I}$ ). Tails of the tail tuft are usually associated with glycogen deposits. Unlike Rhinoclavis, paraspermatozoa of Clypeomorus moniliferus and $C$. breviculus (not figured) did not show any sign of nodular swellings of the nuclear core or spaces within the blocks of the mosaic sheath.

\footnotetext{
* Very recently, a review of the genus Clypeomorus has appeared (Houbrick, 1985). According to this review, the species identified as Clypeomorus moniliferus and Clypeomorus breviculus in the present paper should be referred to as Clypeomorus bifasciata bifasciata (Sowerby) and $\mathrm{Cly}$ peomorus subbrevicula (Oostingh) (C. moniliferus synonomised with $C$. bifasciata; $C$. breviculusname unavailable for use).
}

Fig. 1. Rhinoclavis vertagus. A Transverse section of acrosome-like structure $(\times 85000)$; B Acrosome-like structure and apical portion of mosaic sheath and nuclear core $(\times 37600)$; C Longitudinal section (acrosome-like structure oblique) through head and portion of midpiece, showing attachment of multiple axonemes to base of nuclear core - note nodular swellings in nuclear core (arrows) and spherical spaces in blocks of mosaic sheath $(\times 25900)$; D Oblique transverse section of mosaic sheath and nuclear core - note spherical space in dense block $(\times 29400)$; E Transverse section (slightly oblique) through midpiece showing five axonemes and interspersed mitochondria $(\times 22100) ; F, G$ Longitudinal sections through base of head, midpiece and tail tuft - note pronounced difference in length of midpiece between these two paraspermatozoa and also presence of dense ring structures $(F \times 26530, G \times 21220)$. co - cone of acrosome-like structure; $d b-$ dense blocks of mosaic sheath; drs - dense ring structure; $\mathrm{M}$ - midpiece; nc-nuclear core; $\mathrm{p}$-dense plug of acrosome-like structure 
182
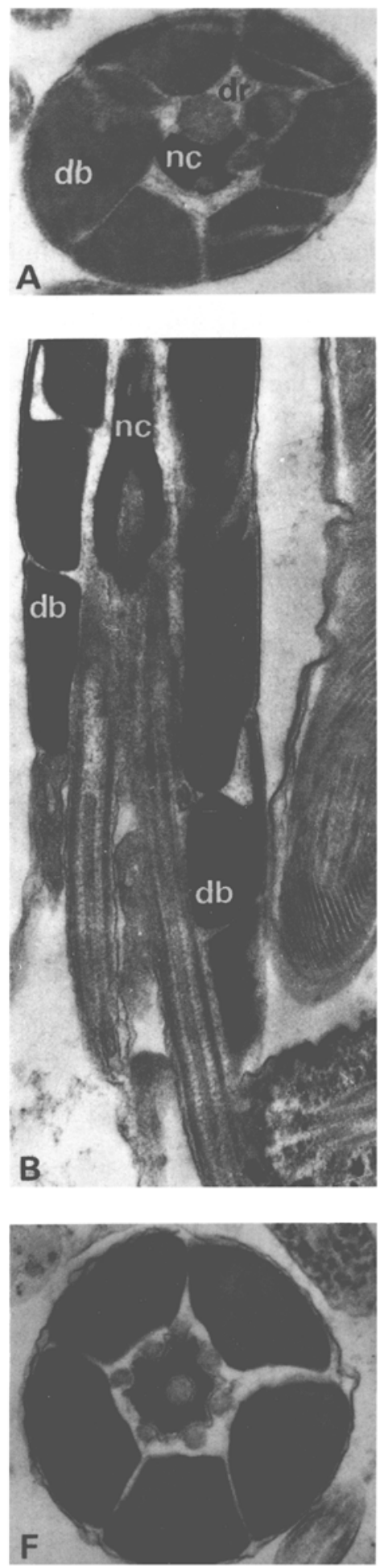

John M. Healy
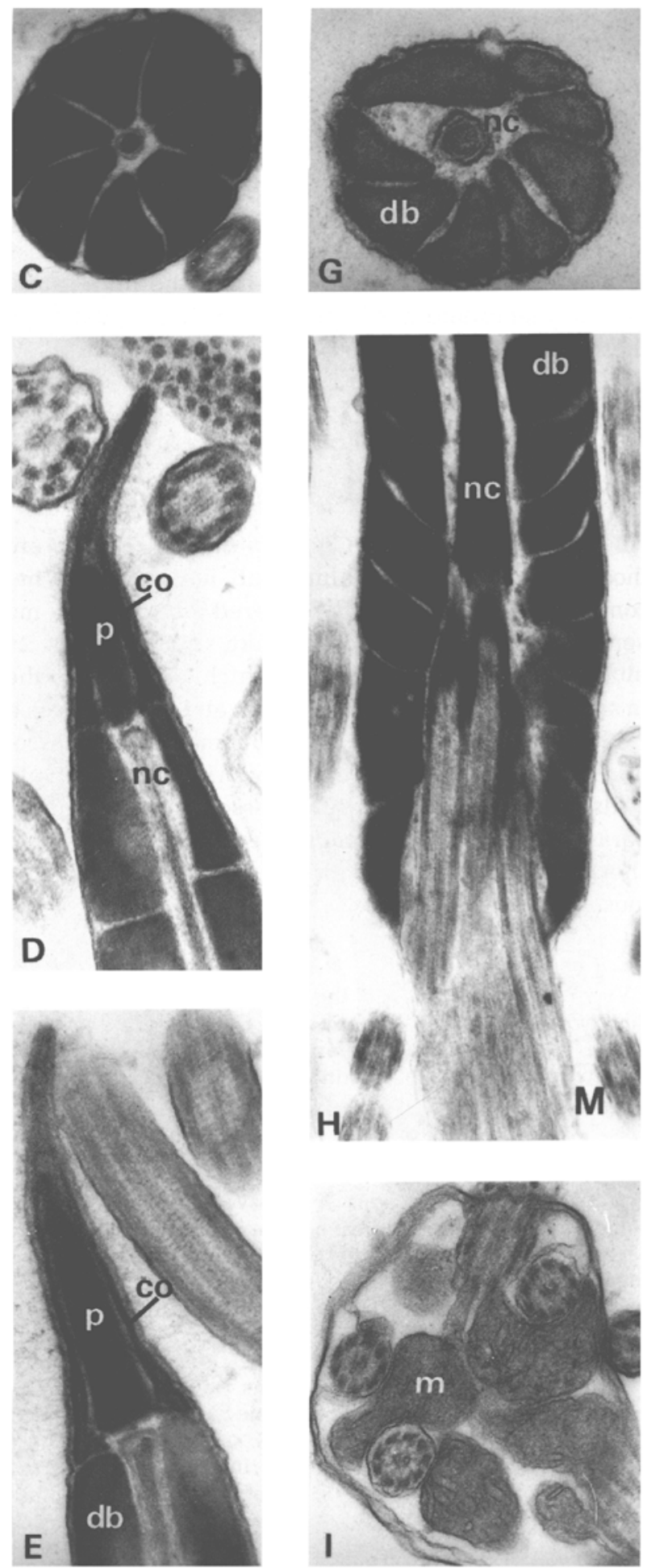
Zeacumantus subcarinatus, Planaxis sulcatus, Zeacumantus lutulentus, and Velacumantus australis

The head and midpiece of Zeacumantus, (Figs $3 \mathrm{~A}, \mathrm{~B}$ ), Velacumantus, and Planaxis (Figs $3 \mathrm{E}-\mathrm{J}$ ) paraspermatozoa, are essentially as described in Rhinoclavis and Clypeomorus (Figs 1,2). The nuclear core becomes finely tapered apically, but basally is thick and forms the attachment site for all axonemes (Figs $3 \mathrm{~A}-\mathrm{C}, \mathrm{E}, \mathrm{F}, \mathrm{H}$ ). All tails of Zeacumantus paraspermatozoa contain dense glycogen deposits (and are each accompanied by a dense ring structure - see Fig. 3A inset), whereas only a single tail exhibits glycogen deposits in Planaxis (Fig. 3J) and Velacumantus (as is also the case in Pyrazus ebeninus, another member of the Batillarinae; cf. Healy \& Jamieson, 1981). Cristae are very well developed in the midpiece of Planaxis paraspermatozoa (Figs $3 \mathrm{I}_{i} \mathrm{~J}$ ). The morphology of the centrioles shown in Figure 3G for Planaxis is consistent with that demonstrated by Healy \& Jamieson (1981) for Pyrazus, and in other cerithiacean paraspermatozoa (for example see Figs $6 \mathrm{E}, \mathrm{F} ; 8 \mathrm{D}, \mathrm{E}$ ). The dense rods which attach the axonemes to the nuclear core in Planaxis, are exceptionally short in comparison with other cerithiacean species (Fig. 3H; cf, Rhinoclavis Fig. 2B, Cerithidea Fig. 7B, Telescopium, Fig. 8C, Diala 5D).

\section{Australaba sp.}

Although fully mature paraspermatozoa of this species (? family) were not observed, those shown in Figure 4 exhibit many of the features encountered in paraspermatozoa of the Cerithiidae, Potamididae, Planaxidae and Turritellidae. The head is composed of a nuclear core, axonemes and deeply intruding mitochondria, all enclosed by the mosaic sheath, and is approximately $30 \mu \mathrm{m}$ in length (Fig. 4). The axonemes attach to the nuclear core (via dense rods) at a level evidently approaching the anterior portion of the head (Figs $4 A, B$ ). The number of axonemes ranges, generally, from ten to seventeen (see Figs $4 \mathrm{~F}, \mathrm{G}$ ), but some sections suggest that as few as four or five axonemes may be present in some cells (see Fig $4 \mathrm{D}, \mathrm{E}$ ). Although the apex of the Australaba paraspermatozoon was not examined in longitudinal section, no direct evidence could be found to establish the existence of an acrosome-like structure. Frequently, spherical 'spaces' or 'vesicles' were seen within dense blocks of the mosaic sheath (Figs $4 \mathrm{~B}, \mathrm{C}$ ). The same phenomenon also occurs in paraspermatozoa of Rhinoclavis vertagus (Cerithiidae - see Figs $1 C, D$ ). It is unlikely that these spaces are artifacts of fixation since they are not

Fig. 2. Rhinoclavis vertagus, Clypeomorus moniliferus. A, B Rhinoclavis: A Transverse section through head showing attachment of three dense rods to nuclear core $(\times 36100)$; B Axonemes attach to base of nuclear core via dense rods $(\times 30270) ; \mathrm{C}-\mathrm{I}$ Clypeomorus: $\mathrm{C}$ Transverse section through head showing nuclear core surrounded by dense blocks of mosaic sheath $(\times 30850)$; D. E Longitudinal sections showing acrosome-like structure and apical portion of mosaic sheath and nuclear core of two paraspermatozoa $(\times 50220)$; F Transverse section through base of head showing attachment of seven dense rods to nuclear core $(\times 33920)$; $G$ Transverse section approaching base of head $(\times 44520)$; $\mathrm{H}$ Axonemes attach to nuclear core at base of head (each via a dense rod) $(\times 29250)$; I Transverse section (slightly oblique) through midpiece $(\times 32800)$. co - cone of acrosome-like structure; $\mathrm{db}$ - dense blocks of mosaic sheath; dr - dense rod of axonemal attachment complex; $\mathrm{m}$ - mitochondria; $\mathrm{M}$ - midpiece; nc - nuclear core; $\mathrm{p}$ - dense plug of acrosome-like 
John M. Healy
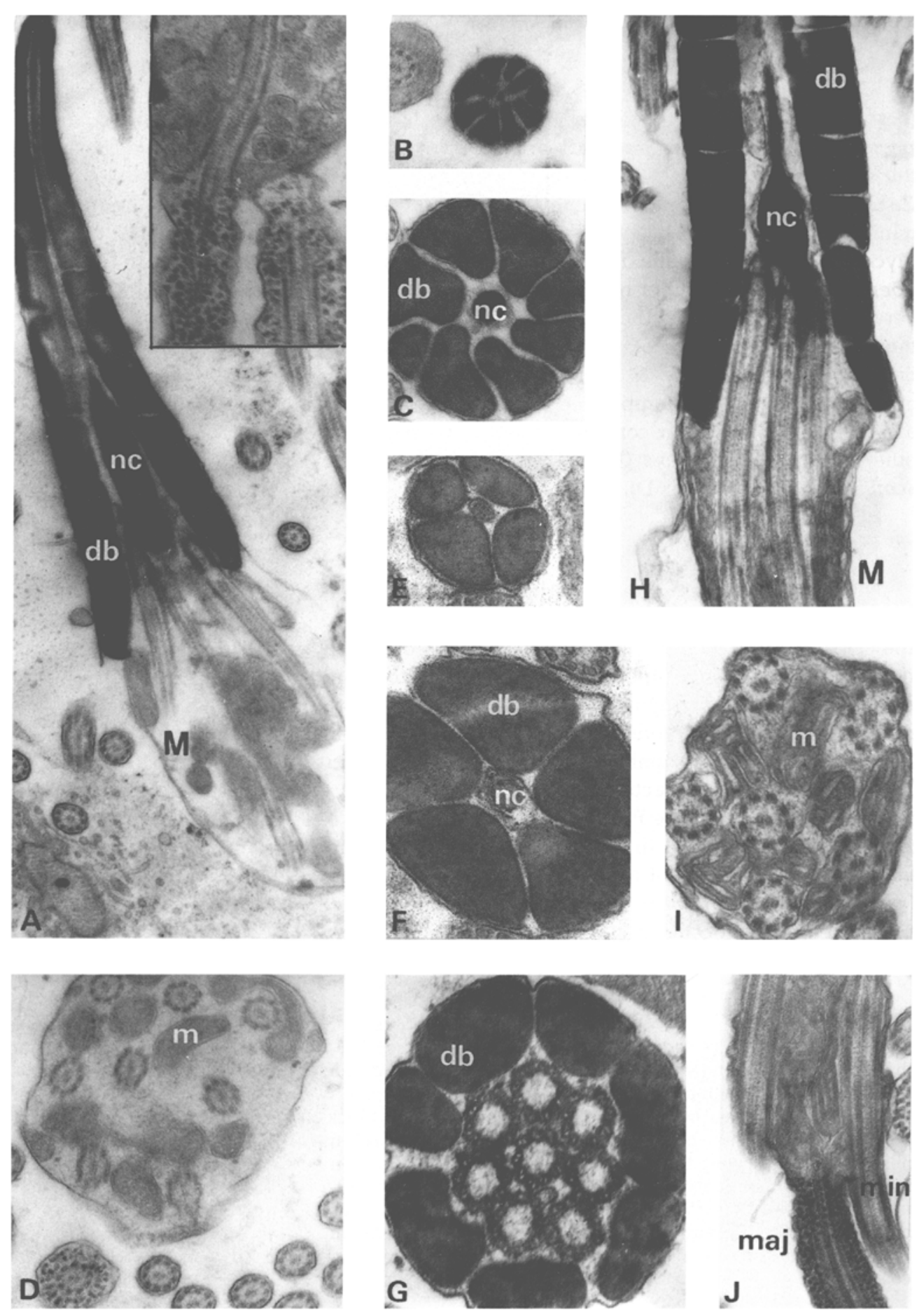
present in paraspermatozoa of most species examined in this study (e.g. Cerithidea, Telescopium, Clypeomorus). The morphology of the tail region (length approximately $33 \mu \mathrm{m})$ could not be satisfactorily determined owing to the immaturity of the cells examined.

\section{Diala cento}

Only alcoholic-formalin fixed specimens of this species were available for study, but in view of the extraordinary differences between the paraspermatozoa of Diala cento (Dialidae) and those of other cerithiaceans, the results are presented here.

The paraspermatozoon apex is composed of a wide, electron-dense cap to which are anchored (via dense rods of the attachment complexes) approximately ninety tightly packed axonemes (Figs $5 \mathrm{~A}-\mathrm{E}$ ). Since the axonemal attachment complexes of many other cerithiacean (and some non-cerithiacean) paraspermatozoa are fixed to a remnant of the nucleus, it is possible that the dense cap at the apex of the Diala paraspermatozoon may also be of nuclear origin. A large, almost spherical space is commonly present within the cap (cf. Fig. 5E), but whether it actually represents a consistent feature of these cells remains to be determined. The axonemes remain bunched for approximately 7.5-8 $\mu \mathrm{m}$ (thereby forming the anterior portion of the paraspermatozoon; cf. Figs $5 \mathrm{~B}, \mathrm{C}$ ), but as they continue into the main body region (characterized by the presence of large, electrondense vesicles), half become distributed peripherally (sometimes in clumps) while the remainder continue as a central bundle (cf. Figs $5 \mathrm{~F}-\mathrm{H}$ ). Owing to the poor preservation of the large vesicles and virtual absence of the plasma membrane, it is difficult to determine whether axonemes branching out from the body (cf. Figs $5 \mathrm{~B}$, I) represent the numerous short tails illustrated by Tochimoto $(1967$, Diala varia) or have been displaced laterally during fixation (because of the absence of a plasma membrane). Certainly features of Diala cento paraspermatozoa described herein (apical cap, anterior region, vesicles, large number of axonemes/emergent tails) are totally in accord with Tochimoto's figure. Nevertheless, a reinvestigation of Diala paraspermatozoa using glutaraldehyde-fixed tissues would be desirable to test the accuracy of the results shown in this study. The full length of Diala cento paraspermatozoa was not determined, but that of Diala varia measures approximately $216 \mu \mathrm{m}$ (cf. Tochimoto, 1967).

Fig. 3. Zeacumantus subcarinatus, Planaxis sulcatus. A-D Zeacumantus: A Longitudinal section through head and midpiece of paraspermatozoon $(\times 15510)$, Inset: tails with glycogen deposits $(\times 15500) ; B, C$ Transverse sections through apical and middle regions of head $(\times 21680) ; D$ Transverse section through midpiece $(\times 21700)$. E-J Planaxis: E, F Transverse sections through apical and middle region of head $(\times 51240)$; $G$ Transverse section through head at level of multiple centrioles $(\times 48570) ; H$ Attachment of axonemes to base of nuclear core - dense rods are exceptionally short $(\times 24600)$; I Transverse section through midpiece, showing cristae clearly visible in mitochondria $(\times 35620)$; J Point of emergence of tail tuft - note major tail (with glycogen sheath) and minor tails (axoneme surrounded only by plasma membrane) $(\times 22800)$. db - dense blocks of mosaic sheath; $\mathrm{m}$ - mitochondria; $\mathrm{M}$ - midpiece; maj-major tail; min - minor tails; ncnuclear core 

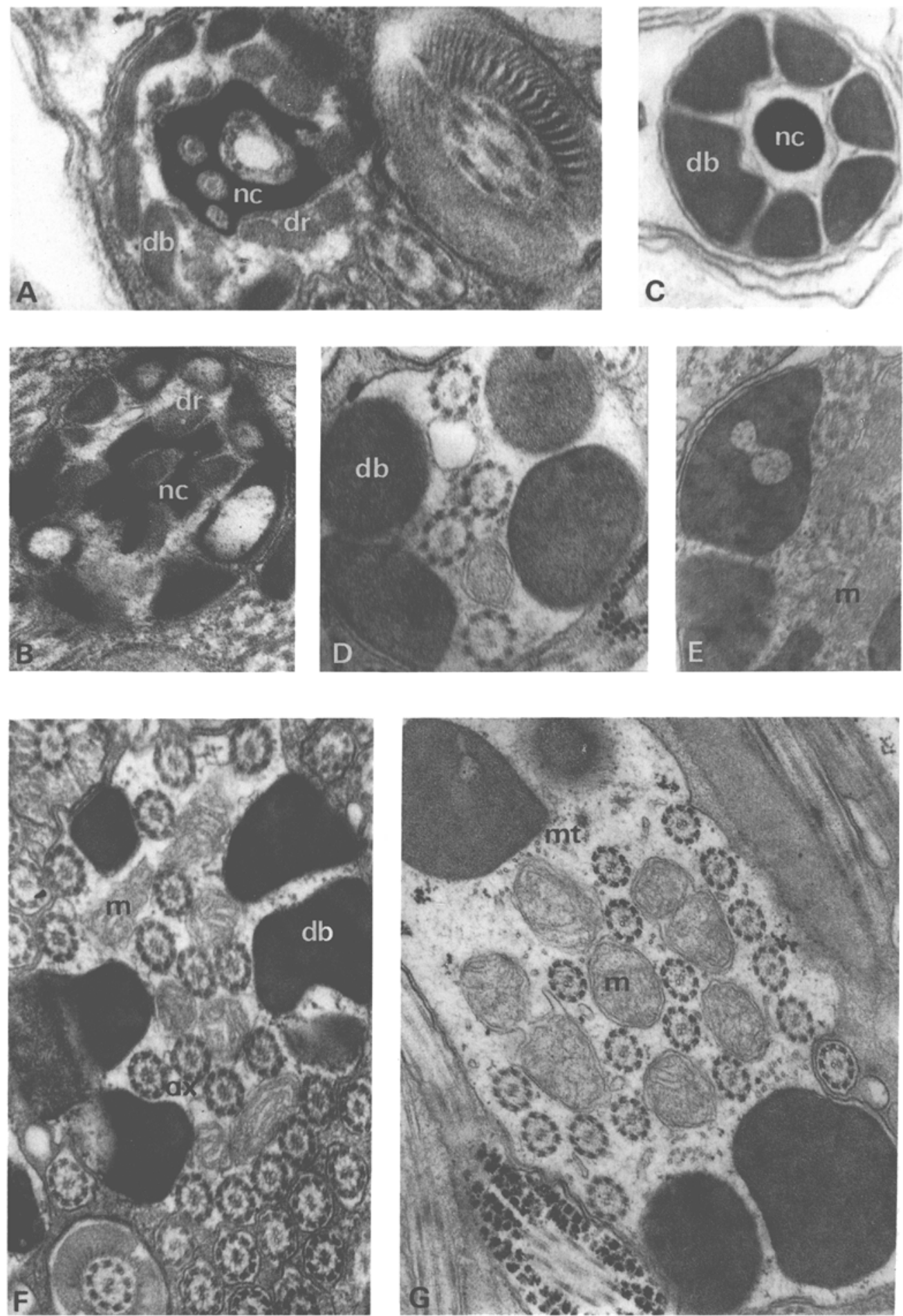


\section{Cerithidea largillierti, C. obtusa and Telescopium telescopium}

As observed in the paraspermatozoa of Rhinoclavis, Clypeomorus, Zeacumantus and Planaxis, the paraspermatozoan heads of Cerithidea (C. largillierti, C. obtusa) and Telescopium are divisible into an acrosome-like structure (Figs $6 \mathrm{~B}, \mathrm{C} ; 7 \mathrm{C}, \mathrm{D}, \mathrm{F}$ ), followed posteriorly by the nuclear core and mosaic sheath (Figs $6 \mathrm{~A}-\mathrm{G} ; 7 \mathrm{~A}-\mathrm{F} ; 8 \mathrm{~A}-\mathrm{E}$ ). Paraspermatozoa of Cerithidea and Telescopium (Potamidinae) differ from those of Rhinoclavis, Clypeomorus, Zeacumantus, Pyrazus, Planaxis and Velacumantus in the following features: (1) the penetration of the nuclear core into the base of the acrosome-like structure (that is, the tip of the nuclear core and not a dense plug of material occupies the basal invagination of the cone; cf. Figs $6 \mathrm{~B}, \mathrm{C} ; 7 \mathrm{D}, \mathrm{E}) ;(2)$ increased length of the head $(15-20 \mu \mathrm{m}$ ) and degree of penetration of the head by the axonemes (Figs $6 \mathrm{D}-\mathrm{G} ; 7 \mathrm{~A}, \mathrm{~B}, \mathrm{~F}$ ); (3) increased number of axonemes (up to 16). The morphology of each axonemal attachment complex is as observed in other cerithiaceans (that is, $9+2$ axonemes each succeeded by $9+0$ [centriolar region], centriolar cap, dense attachment rod) with the possible exception that the attachment rod is often long (Figs 7B, 8C). Axonemes (10-16 in number) often penetrate deeply into the head region (Figs $6 \mathrm{E}, \mathrm{F} ; 7 \mathrm{~A}$ ), and usually attach to the nuclear core (Figs $7 \mathrm{G}, 8 \mathrm{~B}$ ). The sometimes close spatial relationship of dense rods (of attachment complexes) to the mosaic sheath (for example Figs $7 \mathrm{~B}, \mathrm{C}_{\mathrm{i}}$ $8 \mathrm{C}-\mathrm{E}$ ), suggests that at least some of the axonemes may attach to blocks of the mosaic sheath. Many mitochondria are often observed at the base of the head, showing that considerable overlap of 'midpiece' and 'head' regions occur in these paraspermatozoa (cf. Figs $6 \mathrm{G} ; 8 \mathrm{~A}, \mathrm{D}, \mathrm{E}$ ). Figures $6 \mathrm{G}$ and $8 \mathrm{D}, \mathrm{E}$ show that the multiple axonemes at or near the base of the head are separated by membrane barriers, the origins of which are not known (possibly membranes eliminated by coalescing mitochondria). At the junction of midpiece and tail tuft, dense ring structures are seen - one associated with each tail (cf. Fig. 8C). All tails have deposits of electron-dense 'glycogen' granules (Figs 6H, 8C). The average length for the tail tuft region is between 30 and $50 \mu \mathrm{m}$.

\section{Obtortio cf. fulva}

A full description of the paraspermatozoa of Obtortio cf. fulva (? family position) is given by Healy (1982). Briefly the main features of this paraspermatozoan type are: (1) a head composed of a mosaic sheath surrounding up to ten axonemes, (2) an apical structure to which the axonemes are attached (via dense rods), (3) long mitochondria interspersed with the axonemes (within the head), (4) a short 'midpiece' region (axonemes and mitochondria enclosed by plasma membrane only), (5) a tail tuft (each

Fig. 4. Australaba sp. A, B Transverse sections through nuclear core and attached dense rods (which anchor axonemes to nuclear core) - note spherical spaces in dense blocks in Figure $4 \mathrm{~B}(\mathrm{~A} \times 59820$; $B \times 42570$ ), C Transverse section of head above level of axoneme attachment to nuclear core $(\times 44600)$; $D$ Transverse section below level of nuclear core showing single mitochondrion and four axonemes ( $\times 41300)$; $E$ Two spherical spaces in a dense block connected to each other $(\times 32780)$; F Transverse section approaching base of head - note interspersed axonemes and mitochondria $(\times 33670)$; G Transverse section at base of head $(\times 28670)$. ax - axonemes; db - dense blocks of mosaic sheath; dr - dense rods of axonemal attachment complex; $m$ - mitochondria; mt microtubules; nc - nuclear core 

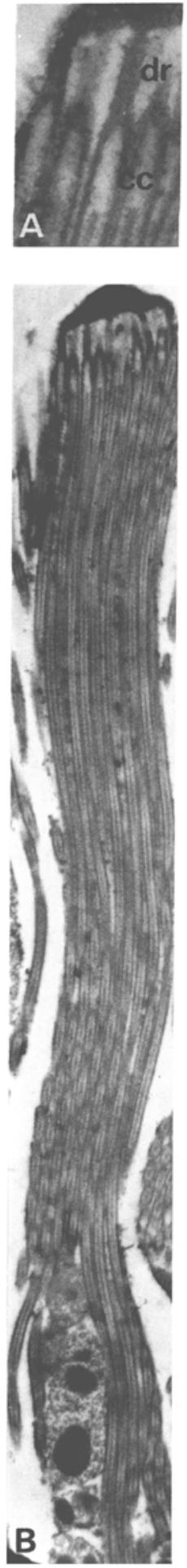
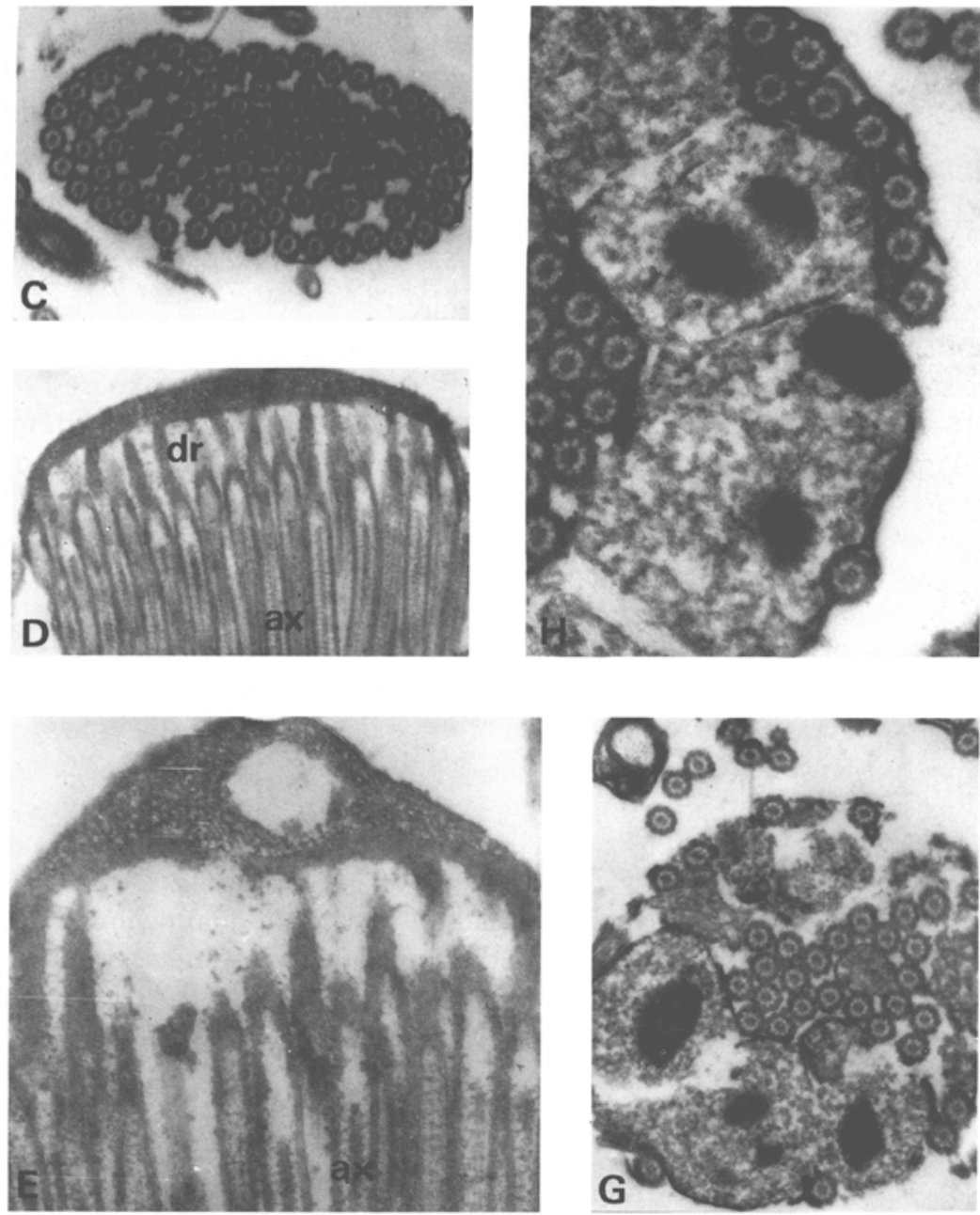
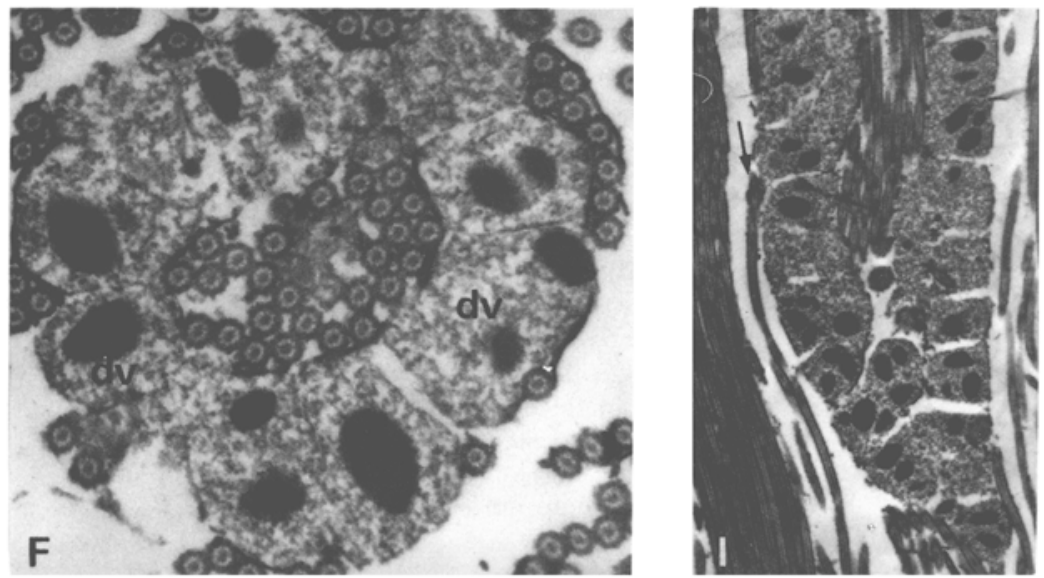
axoneme surrounded by glycogen granules and plasma membrane, each tail associated with a dense ring structure at junction with midpiece).

\section{Campanile symbolicum}

Paraspermatozoa of the Australian relict species Campanile symbolicum (Campanilidae) are described in a separate paper (Healy, 1986). However, a brief résumé of distinguishing features is worth presenting here. Unlike other cerithiaceans, $C$. symbolicum produces two types of paraspermatozoa, both with a head (featuring an acrosome-like structure) and tail tuft (two or three tails). Differences between the two types of paraspermatozoa can be summarized as follows: nucleate paraspermatozoa - head with nuclear core; two or three axonemes attached to base of nuclear core; (2) anucleate paraspermatozoa - head without nuclear core; mitochondria and axonemes penetrating almost to base of acrosome-like structure; two axonemes apparently attached to mosaic sheath; blocks of mosaic sheath only partly surrounding axonemes and mitochondria (mitochondria essentially taking the place of the nuclear core).

Figure 9 summarizes the morphology of cerithiacean gastropod paraspermatozoa, using as examples Rhinoclavis, Telescopium/Cerithidea, Campanile, Diala and Obtortio.

\section{DISCUSSION}

\section{Structural comparison}

Probably the most surprising result to emerge from the present study is the extremely unusual morphology of the paraspermatozoa of Diala. Tochimoto's (1967) illustration of Diala varia paraspermatozoa (as observed with light microscopy) has been very useful in reconstructing the form of Diala cento paraspermatozoa examined herein (only imperfectly preserved material available; cf. Figs $5 \mathrm{~A}-\mathrm{I}$ ). In some characteristics notably the presence, anteriorly, of very large numbers of closely packed axonemes paraspermatozoa of Diala cento approach those of the Epitoniacea (see Bulnheim, 1962; Melone et al., 1978, 1980). Unlike paraspermatozoa of epitoniaceans, those of Diala cento (and $D$. varia) do not support clumps of attached euspermatozoa (that is, do not form spermatozeugmata). More importantly, euspermatozoa of Diala cento (and presum-

Fig. 5. Diala cento. A Detail of Figure 5B showing axonemal attachment complexes fixed to apical cap $(\times 22470)$; B Anterior region of paraspermatozoon - note apical cap, attached, tightly packed axonemes $(\times 8360)$; $C$ Transverse section through anterior region of paraspermatozoon, showing approximately ninety axonemes and the compressed shape of this region $(\times 14170)$; D Apical cap and attached axonemes ( $\times 16000)$; E Apical cap and attached axonemes - note spherical space in the apical cap ( $\times 34000) ; F, G$ Transverse sections through main body region of paraspermatozoa showing axonemes distributed centrally and in clumps peripherally - poor preservation of the dense vesicles (which appear to be block-shaped from their outlines) is probably due to alcoholicformalin fixation of tissues $(\times 18370)$, HDetail of peripheral axonemes with intact portion of the plasma membrane $(\times 28500)$; I Oblique longitudinal section through a portion of the main body region showing (arrow) possible emergent tails ( $\times$ 5940), ax-axonemes; cc - centriolar cap(s); dr dense rods of axonemes attachment complexes; $d v$ - dense vesicles 


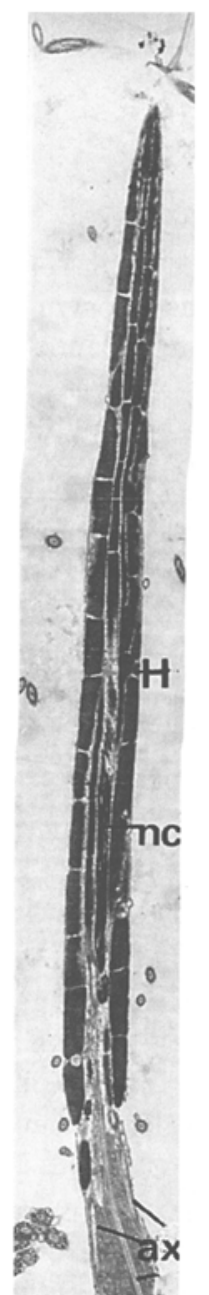

A am
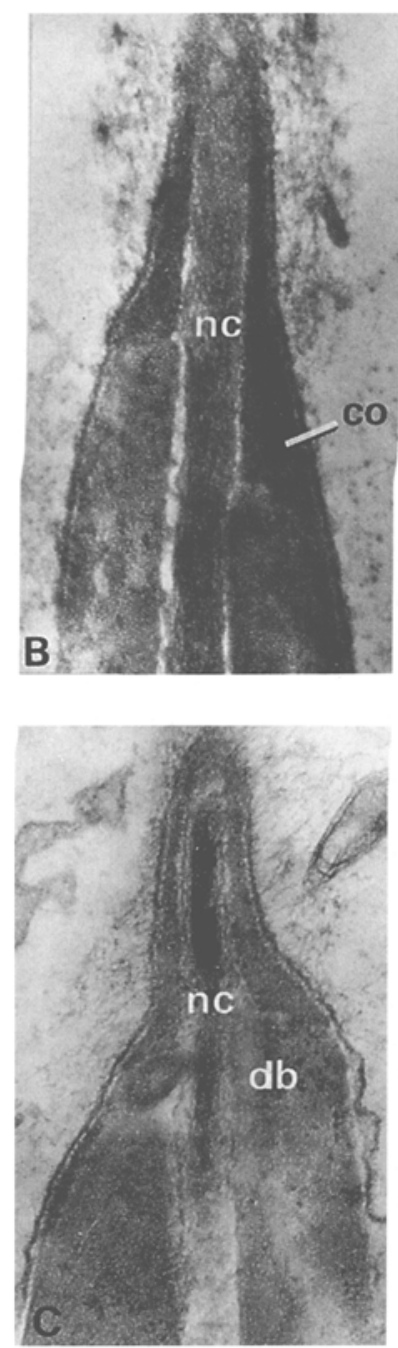
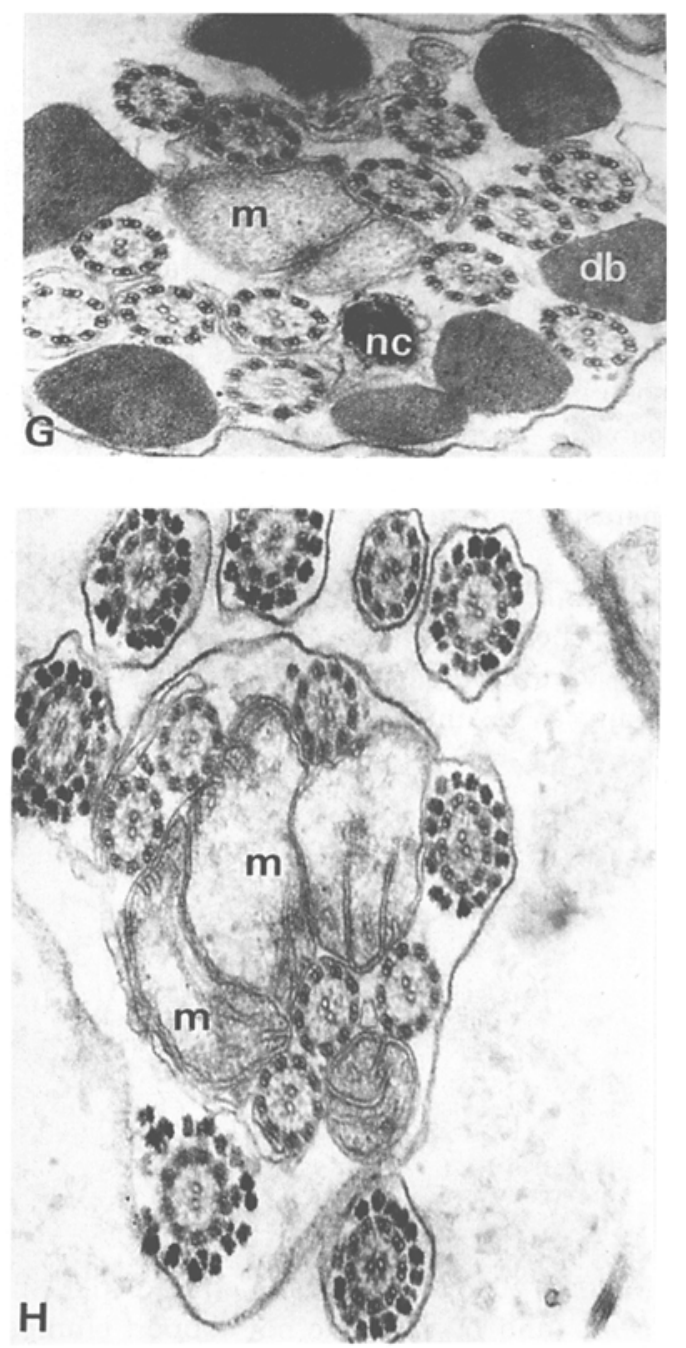
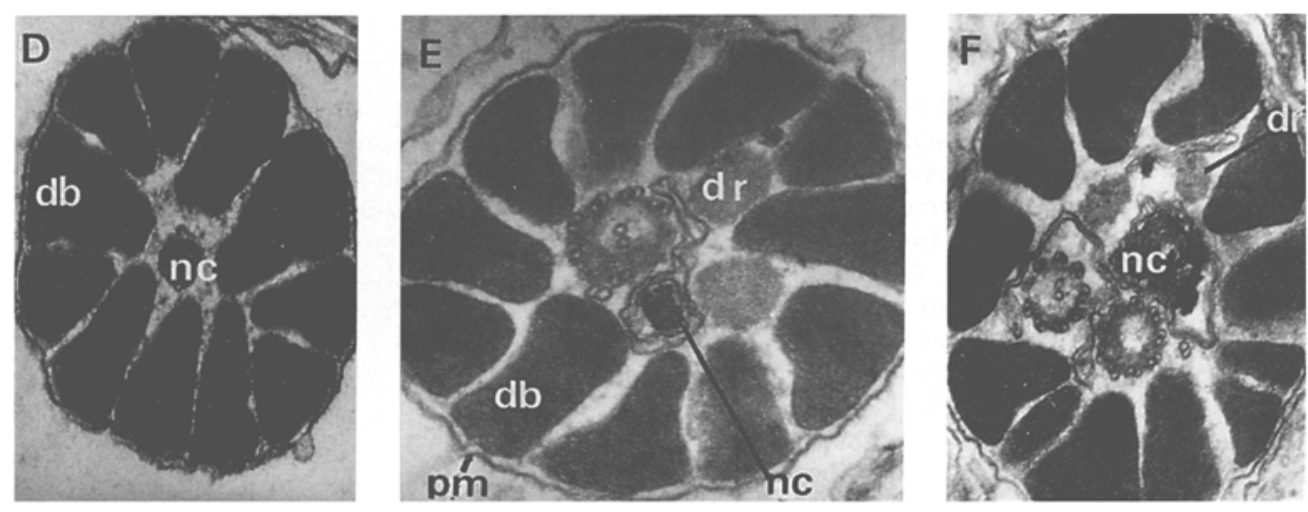
ably other members of the Dialidae) are unmistakingly cerithiacean in form (Healy, 1984).

Aside from Diala, the paraspermatozoa of most cerithiacean gastropods bear a close resemblance to those produced in two other mesogastropod superfamilies, the Viviparacea (see Ishizaki \& Kato, 1958; Yasuzumi \& Tanaka, 1958; Gall, 1961; Anderson \& Personne, 1970; Griffond, 1981) and the Cyclophoracea (see Selmi \& Giusti, 1980). These similarities include the presence of a tail tuft, mosaic sheath and nuclear remnant, and are discussed at length by Healy \& Jamieson (1981) and Healy (1982). The acrosome-like structure and midpiece which are observed in many cerithiacean paraspermatozoa (herein; Healy \& Jamieson, 1981) have not been demonstrated in any other prosobranch superfamily.

In paraspermatozoa of most mesogastropods and neogastropods (commonly vermiform, occasionally large and tripartite or with undulating lateral 'membranes') the axonemes are totally or almost totally confined within the cell body. During the early stages of development, these axonemes form multiple, mobile tails, but as spermiogenesis proceeds, the tails gradually are drawn into the cell, until at maturity all axonemes lie within the paraspermatozoon body (cf. Reinke, 1914; Tuzet, 1930; Ankel, 1958; Bulnheim, 1968; Buckland-Nicks et al., 1982). The Cerithiacea, Viviparacea and Cyclophoracea differ from other mesogastropods and the Neogastropoda in their retention of multiple mobile tails in mature paraspermatozoa. These tails in cerithiacean and viviparacean paraspermatozoa are associated with glycogen deposits (Anderson \& Personne, 1970; Hachiri \& Higashi, 1972; Healy, 1982, herein) and at least in the Cerithiacea are usually preceeded by a dense ring structure (as observed in euspermatozoa of cerithiaceans and other meso- and neogastropods; cf. Healy, 1983b).

The nucleus completely or almost completely disintegrates during paraspermatozoan development in most mesogastropod and neogastropod species (cf. Reinke, 1914; Bulnheim, 1968; Buckland-Nicks et al., 1982). In the developing paraspermatozoa of many cerithiaceans (Healy \& Jamieson, 1981; pers. observ.) and the cyclophoracean Cochlostoma montanum (cf. Selmi \& Giusti, 1980), the nucleus undergoes a pattern of condensation similar to that occurring in euspermiogenesis. While features such as the retention of multiple tails, condensation of nuclear contents and possession of an acrosome-like structure (and a midpiece) seem to suggest that paraspermatozoan development within the Cerithiacea has remained at a relatively 'primitive' level (in relation to other mesogastropods), results presented here for Diala clearly show that this

Fig. 6. Cerithidea obtusa, Cerithidea largillierti. A, B C. obtusa: A Head and midpiece $(\times 5340)$; $B$ Acrosome-like structure (oblique anteriorly) showing penetration of nuclear core into invaginated base of cone $(\times 68860)$; $\mathrm{C}-\mathrm{F}$ C largillierti: $\mathrm{C}$ Acrosome-like structure, showing nuclear core penetrating into base of cone $(\times 69570)$; D-F Series of transverse sections from anterior to middle region of paraspermatozoon head, - note close association of dense attachment rods to blocks of mosaic sheath as well as the nuclear core (D, $E \times 45830 ; F \times 44500$ ); G Transverse section near base of head, showing persistence of nuclear core and penetration of mitochondria into base of head $(\times 39800)_{i}$ H Transverse section through base of midpiece at point of emergence of tail tuft - each tail consists of an axoneme surrounded by glycogen granules ( $\times$ 42370). ax - axonemes; co - cone of acrosome-like structure; $\mathrm{db}$ - dense blocks of mosaic sheath; $\mathrm{dr}$ - dense rods of axonemal attachment complex; $\mathrm{H}$ - head of paraspermatozoon; $\mathrm{m}$ - mitochondria; $\mathrm{M}$ - midpiece; nc-nuclear 
192
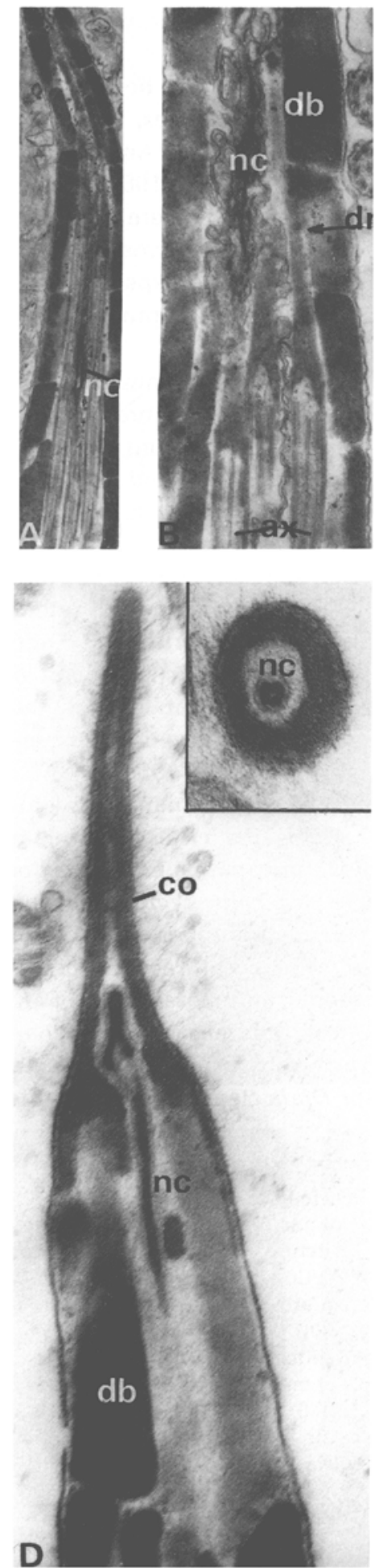

John M. Healy
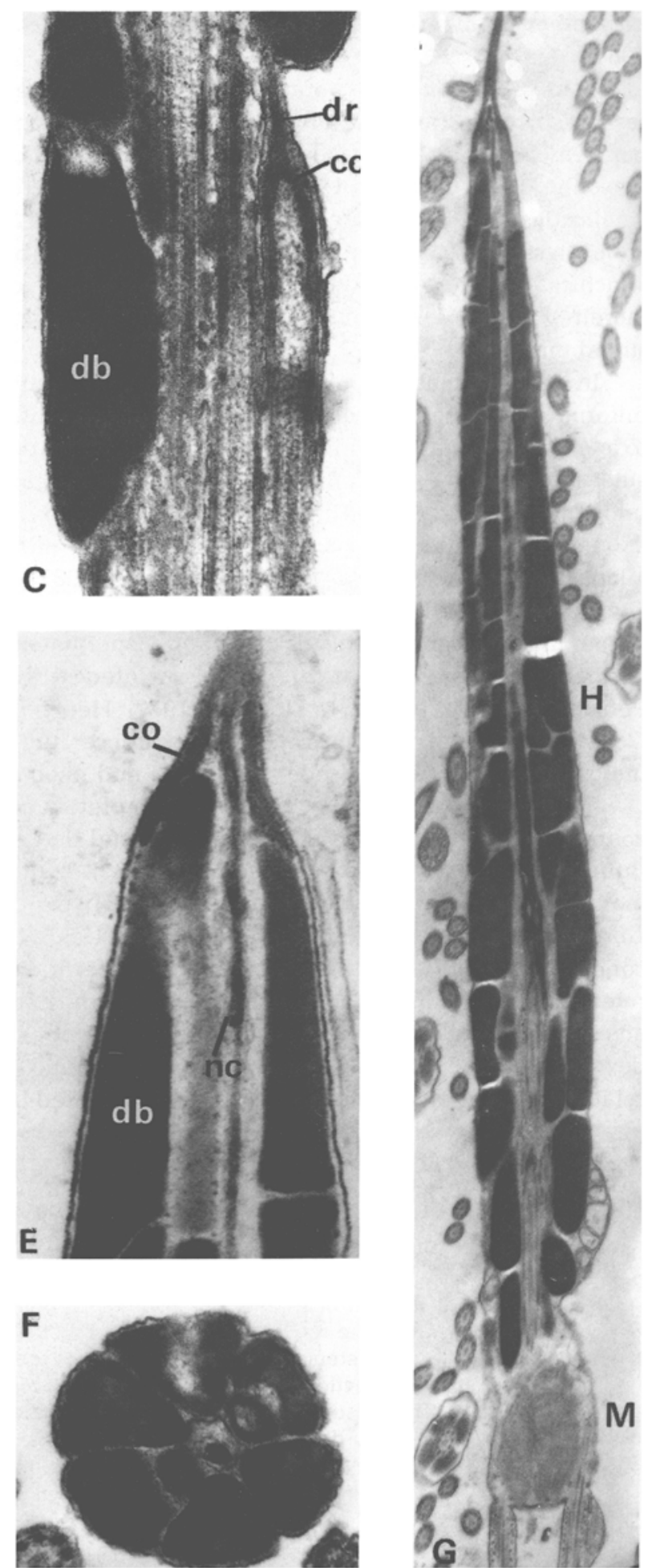
superfamily is capable of producing paraspermatozoa as modified as any other occurring in the Prosobranchia. It is highly probable that continued work on other cerithiacean gastropods will yield other examples of very modified paraspermatozoa.

\section{Systematic importance of cerithiacean paraspermatozoa}

Healy (1983b) used euspermatozoal morphology to divide the Cerithiacea into two broad groups: group I (i) including Cerithiidae, Turritellidae, Australaba (family position uncertain), I (ii) including Planaxidae, Potamididae (subfamily Batillariinae only); group II including Modulidae, Potamididae (subfamily Potamidinae only), Obtortio (? family position) and possibly the Pleuroceridae (more detailed information on the euspermatozoa of pleurocerids is required to confirm this position). Recent additional research by the author indicates that a third group should be established to accomodate Campanile symbolicum (Campanilidae; Healy, 1986), while the Dialidae and Siliquariidae can be added to group I (i).

Electron microscopic studies have shown that the paraspermatozoa of cerithiaceans belonging to group I (cf. Melone et al,, 1980; Healy \& Jamieson, 1981; Giusti \& Selmi, 1982; herein) share a common structural design - the only apparent exceptions to this being paraspermatozoa of Australaba (up to 17 axonemes, deeper penetration of axonemes into head) and those of Diala (extremely unusual cells which possibly characterize this small-shelled family; cf. Figs 5 A-I, also Tochimoto, 1967). Paraspermatozoa of the Potamidinae and Obtortio (both members of group II) differ from those of group I cerithiaceans (generally) in the following features: increased penetration of the head by the axonemes, increased number of axonemes, attachment site of axonemes, presence/absence of a nuclear core, presence/absence of an acrosome-like structure (herein; Healy, 1982). Existing TEM data for paraspermatozoa of the Pleuroceridae (cf. Hachiri \& Higashi, 1971) and Thiaridae (cf. Yasuzumi et al., 1962), merely establishes the existence of a nuclear core and mosaic sheath in each and does not allow any comment to be made on the position of these freshwater families within the Cerithiacea.

Research on paraspermatozoa and particularly euspermatozoa would permit evaluation of the view that the Pleuroceridae and Thiaridae had their origins in the Cerithiidae and Planaxidae, respectively (cf. Morrison, 1954). Such work could also explore the relationship between the Cerithiacea and the entirely freshwater superfamily Vivi-

Fig. 7. Cerithidea obtusa, Telescopium telescopium. A-C, Cerithidea: A Longitudinal section through head, showing nuclear core and axonemes ( $\times 13360)$; B Possible attachment of dense rod (and associated axoneme) to dense block of mosaic sheath ( $\times 26700$ ); $C$ Possible attachment of dense rod (and axoneme) to block of mosaic sheath at base of head - axonemes appear to attach to periphery of block $(\times 43500) ; \mathrm{D}-\mathrm{G}$, Telescopium: D Apex of paraspermatozoon head showing acrosome-like structure, penetration of nuclear core into invaginated base of cone (of acrosome-like structure) and mosaic sheath $(\times 44000)$. Inset: Transverse section of acrosome-like structure and nuclear core ( $\times 69520)$; E Apex of paraspermatozoon - acrosome-like structure (cut obliquely at tip), nuclear core, mosaic sheath (43500); F Transverse section through anterior region of head nuclear core is surrounded by blocks of the mosaic sheath $(\times 35600)$; $\mathrm{G}$ Complete head, midpiece and proximal portion of tail tuft $(\times 9300)$. cc - centriolar cap(s); co - cone of acrosome-like structure; $\mathrm{db}$ - dense blocks of mosaic sheath; $\mathrm{dr}$ - dense rods of axonemal attachment complexe(s); $\mathrm{H}$ - head of paraspermatozoon; $\mathrm{M}$ - midpiece of paraspermatozoon; nc - nuclear core 

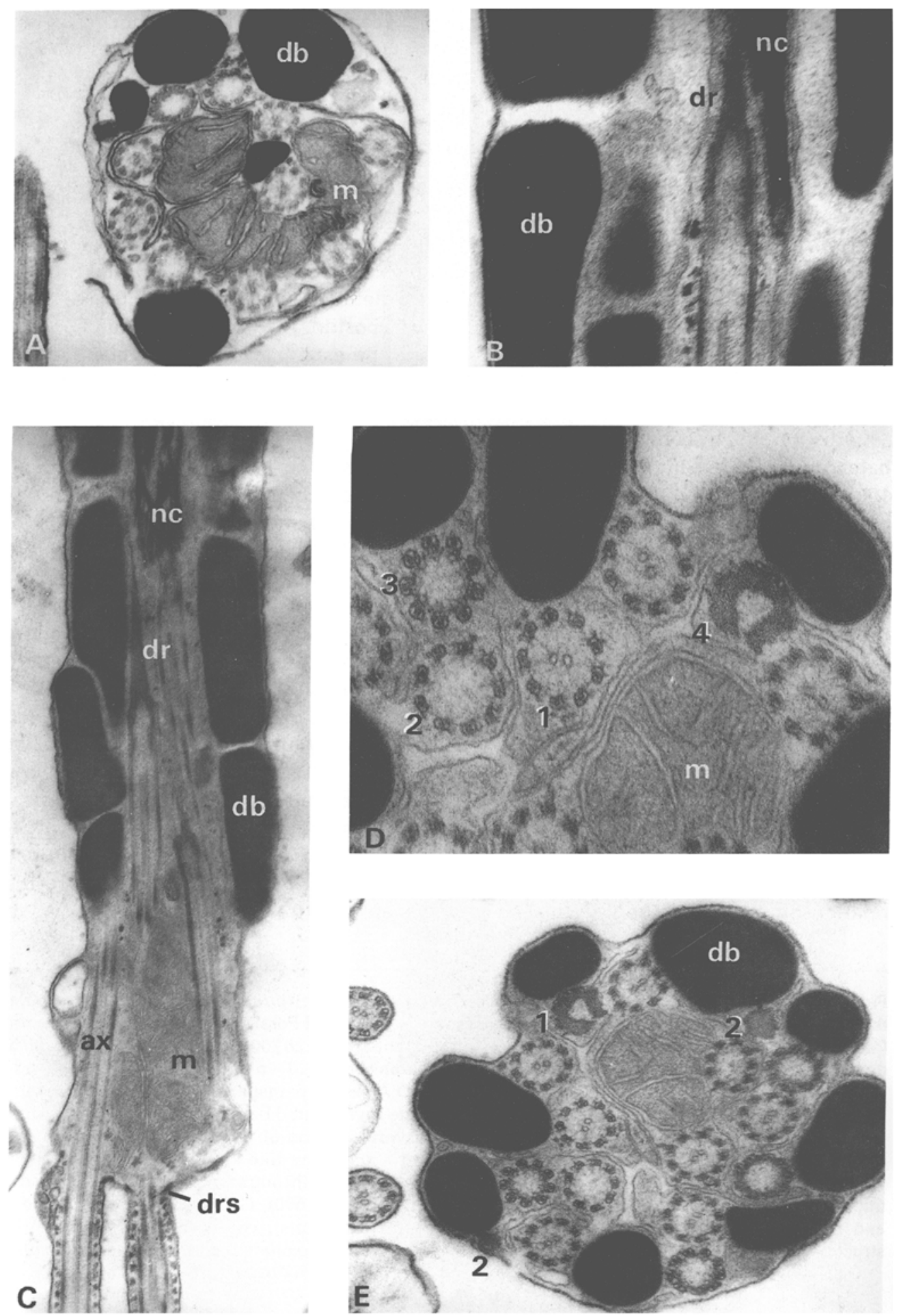
paracea (the euspermatozoa and paraspermatozoa of viviparacean gastropods are similar in many respects to those of the Cerithiacea; cf. Healy \& Jamieson [1981]; Healy [1982, 1983b] for discussion). Although only scanning electron microscopic information is available for paraspermatozoa of the Modulidae (Houbrick, 1980-Modulus modulus), TEM work on the euspermatozoa of Modulus tectum (Healy, 1983 b, 1984) clearly indicates affilation of this family with the Potamidinae and Obtortio (that is, other members of group II). The relict species Campanile symbolicum differs from other cerithiaceans in having: (1) two types of paraspermatozoa (nucleate - with nuclear core, anucleate - without nuclear core) - each of which has only two or three tails, and (2) euspermatozoan midpiece morphology unlike that of any other gastropod species. These sperm features support the opinion of Houbrick (1981) that the Campanilidae should be maintained as a distinct family within the Cerithiacea. The fine structure of Campanile nucleate paraspermatozoa suggests that the Campanilidae is probably allied closest to taxa such as the Cerithiidae, Turritellidae, Batillariinae (group I), but further research will be necessary to confirm this. A full description and discussion of the euspermatozoa and paraspermatozoa of Campanile is given in a separate paper (Healy, 1986).

At this point, some mention should also be made of the paraspermatozoa of other families wich are usually or at least occasionally included within the Cerithiacea, namely the Cerithiopsidae, Vermetidae (as restricted by Morton, 1955) and the Triphoridae. Both the Cerithiopsidae and Triphoridae produce large paraspermatozoa to which clumps of mature euspermatozoa are attached (spermatozeugmata; Fretter \& Graham, 1962; Healy, 1984). Very similar spermatozeugmata have been recorded throughout the Epitoniacea (cf. Ankel, 1958; Bulnheim, 1962, 1968; Graham, 1954; Nishiwaki, 1964; Tochimoto, 1967; Nishiwaki \& Tochimoto, 1969; Melone et al., 1978, 1980; Robertson, 1983). Paraspermatozoa of the Vermetidae (sensu stricto) do not closely resemble those of other cerithiaceans, and even within the family there appears to be major variation in paraspermatozoal morphology (Nishiwaki, 1964; Hadfield, 1969; Melone et al., 1980; Healy, 1984). Equally significant is the fact that euspermatozoa of investigated cerithiopsid, triphorid and vermetid species (Healy, 1984) have a midpiece organized on a pattern seen in many mesogastropod and neagastropod groups (for example: Littorinacea, Rissoacea, Strombacea, Epitonacea, Naticacea, Tonnacea, Buccinacea, Conacea) but not in the Cerithiacea, Viviparacea or Cyclophoracea. In summary, sperm structure would not support the inclusion of the Cerithiopsidae, Triphoridae or Vermetidae (s. str.) within the Cerithiacea, but does suggest that a relationship exists between the Epitoniacea, Cerithiopsidacea and Triphoracea.

Fig. 8. Telescopium telescopium. A Transverse section through head/midpiece junction - transition from axoneme $(9+2)$ to centriole $(9+0)$ visible $(\times 35860)$; B Detail of dense rod attachment to nuclear core $(\times 48900)$; $C$ Longitudinal section through base of head and midpiece - note long dense attachment rod (? fixed to dense block of mosaic sheath), dense ring structures associated with each tail $(\times 21540)$; D Detail of Fig. 8E showing axoneme (1), loss of central microtubules (2), linkage of doublets (3), centriolar cap (4) $(\times 73970)$; E Transverse section through head/midpiece junction - note centriolar cap (1), dense attachment rods (2), apparently fusing to dense blocks; note also membrane which divides the multiple axonemes (? origins) ( $\times$ 42800). ax - axonemes; db dense blocks of mosaic sheath; $\mathrm{dr}$ - dense rod of axonemal attachment complex; drs - dense ring structure; $\mathrm{m}$ - mitochondria; $\mathrm{nc}$ - nuclear core 


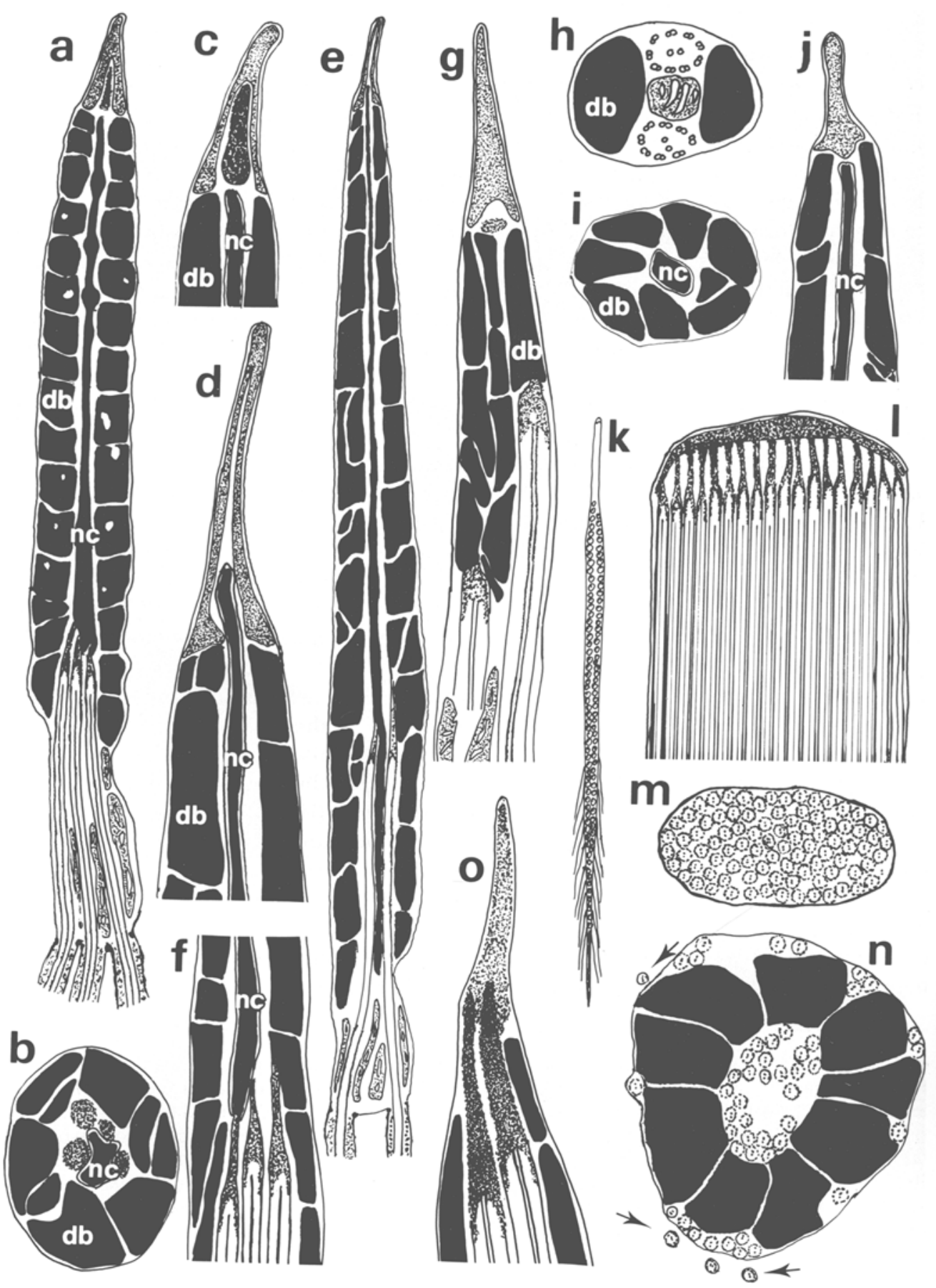


Understanding of the systematics of cerithiacean gastropods and indeed the relationship of this large and important superfamily to other mesogastropods, will inevitably improve as ultrastructural data on the paraspermatozoa and euspermatozoa continue to accumulate.

Acknowledgements. The author would like to thank Dr. B. G. M. Jamieson and Dr. R. C. Willan (both of the Department of Zoology, University of Queensland) for providing a number of very constructive comments on the manuscript. The following people either collected or assisted the author in collecting specimens used in this study: Dr. R. C. Willan, Mr. and Mrs. T. \& M. Stewart (Brisbane), Mr. and Mrs. H. \& B. Collins (Cairns). Dr. W. F. Ponder (Australian Museum, Sydney) identified the Australaba material used in this study. The combined assistance of the staff of the University of Queensland Electron Microscope Unit is also gratefully acknowledged. Annual University Commission Grants and a Commonwealth Postgraduate Award assisted the author in completing this work, which initially formed part of a Ph. D. thesis (supervisor, Dr, B. G. M. Jamieson).

\section{LITERATURE CITED}

Anderson, W. A. \& Personne, P., 1970. The localization of glycogen in the spermatozoa of various invertebrate and vertebrate species. - J. Cell Biol, 44, 29-51.

Ankel, W. E., 1958. Beobachtungen und Überlegungen zur Morphogenese der atypischen Spermien von Scala clathrus L. - Zool. Anz. 160, 261-276.

Buckland-Nicks, J. A., Williams, D., Chia, F.-S. \& Fontaine, A., 1982. Studies on the polymorphic spermatozoa of a marine snail. I. Genesis of the apyrene sperm. - Biol. Cell. 44, 305-314.

Bulnheim, H.-P., 1962. Elektronenmikroskopische Untersuchungen zur Feinstruktur der atypischen und typischen Spermatozoen von Opalia crenimarginata (Gastropoda, Prosobranchia). - Z. Zellforsch. mikrosk. Anat. 56, 371-386.

Bulnheim, H.-P., 1968. Atypische Spermatozoenbildung bei Epitonium tinctum. Ein Beitrag zum Problem des Spermatozoendimorphismus der Prosobranchia. - Helgoländer wiss. Meeresunters. $18,232-253$.

Culling, C. F. A., 1974. Handbook of histopathological and histochemical techniques. Butterworth, London, $712 \mathrm{pp}$.

Fig. 9. Paraspermatozoon morphology in the Cerithiacea. All figures except Figure $9 \mathrm{k}$ traced from or based upon actual micrographs. Figure 9k based on Fig. 2 (15) of Tochimoto (1967 - paraspermatozoon of Diala varia). a-c Paraspermatozoa of the Cerithiidae, Planaxidae, Batillarimae (head 6-8 $\mu \mathrm{m}, 5-8$ tails, axonemes attached to base of nuclear core, acrosome-like structure with plug, e.g. Rhinoclavis vertagus): a Head, midpiece and tail tuft $(\times 15750)$; b Transverse section (T.S.) through base of head showing axonemal attachment rods fixed to nuclear core $(\times 25200)$; c Acrosome-like structure $(\times 26500)$. d-f Paraspermatozoa of the Potamidinae (head 12-18 $\mu \mathrm{m}, 10-16$ tails, axonemes attached to nuclear core or mosaic sheath often deep within head, nuclear core penetrating into base of acrosome-like structure, e.g. Telescopium telescopium [d, e], Cerithidea largilliertii [f]]: $d$ Acrosome-like structure $(\times 31500)$; e Head, midpiece and tail tuft $(\times 15000)$; f Attachment of rods to nuclear core and dense blocks $(\times 20000)$. g-j Paraspermatozoa of Campanile symbolicum, Campanilidae (anucleate paraspermatozoa $[g, h]$; nucleate paraspermatozoa $[i, j]) ; g$ Anterior region of head $(\times 50000) ; h$ T.S. through head $(\times 28500)$; i T.S. through nuclear core and mosaic sheath $(\times 35000) ; j$ Acrosome-like structure and apex of nuclear core/mosaic sheath $(\times 40000)$. $k-n$ Paraspermatozoa of Dialidae: $k$ Whole paraspermatozoon of Diala varia showing anterior region, large vesicles multiple tails $(\times 300) ; 1-n$, Diala cento: 1 Apex of paraspermatozoon showing dense cap and tightly packed axonemes $(\times 12500)$; $m$ T.S. through anterior region showing 90 axonemes $(\times 12500)$; $\mathrm{n}$ T.S. through lower half of body region (reconstructed) showing large dense vesicles, internal axonemes, outlying axonemes and emergent tails (arrows) $(\times 12500)$. (o Obtortio cf. fulva, ? Obtortionidae) Apical structure with attached axonemes (based on micrograph of Healy, 1982) $(\times 30250) . d b-$ dense blocks; nc - nuclear core 
Fretter, V. \& Graham, A., 1962. British prosobranch molluscs. Ray Soc., London, 755 pp.

Gall, J. G., 1961. Centriole replication. A study of spermatogenesis in the snail Viviparus. J. biophys biochem. Cytol. 10, 163-193.

Giusti, $F_{1}$ 1971. L'ultrastruttura dello spermatozoo nella filogenesi e nella sistematica dei molluschi gasteropodi. - Atti Soc. ital. Sci. nat. 112, 381-402.

Giusti, F. \& Selmi, M. G., 1982. The atypical sperm in the prosobranch molluscs. - Malacologia 22, $171-181$.

Graham, A., 1954. Some observations on the reproductive tract of Ianthina janthina (L.). - Proc. malac. Soc. Lond. 31, 1-6.

Griffond, B., 1981. Étude ultrastructurale de la spermatogenèse atypique de Viviparus viviparus (L.), Mollusque Gastéropode. - Archs Biol, Bruxelles 92, 275-286.

Hachiri, S. \& Higashi, S., 1971. Spermiogenesis in the melanian snails Semisulcospira decipiens and Semisulcospira niponica. - Mem. Fac. Educ. Shiga Univ. nat. Sci. 21, 43-51.

Hachiri, S. \& Higashi, S., 1972. Utilization of glycogen in spermatozoa of pond snails, Sinotaia histrica and Heterogen longispira. - Mem. Fac. Educ. Shiga Univ. nat. Sci. 22, 43-57.

Hadfield, M. G., 1969. Nurse eggs and giant sperm in the Vermetidae. - Am. Zool. 9, 1141-1142 (abstr.).

Healy, J. M., 1982. Ultrastructure of paraspermatozoa, euspermatozoa and eusperm-like spermatozoa of Obtortio cf. fulva (Prosobranchia: Cerithiacea). - Helgoländer Meeresunters. 35, $489-500$.

Healy, J. M., 1983a. Ultrastructure of euspermiogenesis in the mesogastropod Stenothyra sp. (Prosobranchia, Rissoacea, Stenothyridae). - Zool. Scr. 12, 203-214.

Healy, J. M, 1983b. Ultrastructure of euspermatozoa of cerithiacean gastropods (Prosobranchia: Mesogastropoda). - J. Morph. 178, 57-75.

Healy, J. M., 1984. The ultrastructure of gastropod spermatozoa and spermiogenesis. Thesis, Univ. Queensland (Brisbane), $370 \mathrm{pp}$.

Healy, J. M., 1986. Euspermatozoa and paraspermatozoa of a relict cerithiacean gastropod Campanile symbolicum (Prosobranchia, Mesogastropoda, Campanilidae). - Helgoländer Meeresunters. 40, 201-218.

Healy, J. M. \& Jamieson, B. G. M., 1981. An ultrastructural examination of developing and mature paraspermatozoa in Pyrazus ebeninus (Mollusca, Gastropoda, Potamididae). - Zoomorphology 98, 101-119.

Houbrick, R. S., 1980. Observations on the anatomy and life history of Modulus modulus (Prosobranchia: Modulidae). - Malacologia 20, 117-142.

Houbrick, R. S., 1981. Anatomy, biology and systematics of Campanile symbolicum with reference to adaptive radiation of the Cerithiacea (Gastropoda: Prosobranchia). - Malacologia 21, 263-289.

Houbrick, R. S., 1985. Genus Clypeomorus Jousseaume (Cerithiidae: Prosobranchia). - Smithson. Contr. Zool. 403, 1-131.

Ishizaki, T. \& Kato, K., 1958. The fine structure of atypical spermatozoa of the pond snail Viviparus malleatus. - Zool. Mag., Tokyo 67, 286-294.

Koike, K. \& Nishiwaki, S., 1980. The ultrastructure of dimorphic spermatozoa in two species of the Strombidae (Gastropoda, Prosobranchia). - Venus, Kyoto 38, 259-274.

Melone, G., Lora Lamia Donin, C. \& Cotelli, F., 1978. Aspetti ultrastrutturali degli spermatozoi atipici in Scalidae (Gastropoda, Prosobranchia). - Boll. Zool. 45, 261-268.

Melone, G., Lora Lamia Donin, C. \& Cotelli, F., 1980. The paraspermatic cell (atypical spermatozoon) of Prosobranchia: a comparative ultrastructural study. - Acta zool., Stockh. 61, 191-201.

Morrison, J. P. E., 1954. The relationships of old and new world Melanians. - Proc. U.S. natn. Mus. $103,357-394$.

Morton, J. E., 1955. The evolution of vermetid gastropods. - Pacif. Sci. 9, 3-15.

Nishiwaki, S., 1964. Phylogenetical study on the type of the dimorphic spermatozoa in Prosobranchia. - Scient. Rep. Tokyo Kyoiku Daig. (B) 2, 237-275.

Nishiwaki, S. \& Tochimoto, T., 1969. Dimorphism in typical and atypical spermatozoa forming two types of spermatozeugmata in two epitoniid prosobranchs. - Venus, Kyoto 38, 37-49.

Reinke, E. E., 1914. The development of the apyrene spermatozoa in Strombus bituberculatus. Pap. Tortugas Lab. 183, 195-239. 
Robertson, R., 1983. Observations on the life history of the wentletrap Epitonium albidum in the West Indies. - Am. malacol. Bull. 1, 1-12.

Selmi, M. G. \& Giusti, F., 1980. Structure and function in typical and atypical spermatozoa of Prosobranchia (Mollusca), I. Cochlostoma montanum (Issel) Mesogastropoda. (1). - Atti Accad. Fisiocr. Siena, 1980, 115-147.

Siebold, C. T. von, 1836. Fernere Beobachtungen über die Spermatozoen der wirbellosen Tiere. Il. Die Spermatozoen der Paludina vivipara. - Arch. Anat. Physiol. wiss. Med. 1836, 232-255.

Tochimoto, T., 1967. Comparative histochemical study of the dimorphic spermatozoa of the Prosobranchia with special reference to polysaccharides. - Scient. Rep. Tokyo Kyoiku Daig. (B) 13, 75-109.

Tuzét, O., 1930. Recherches sur la spermatogenèse des prosobranches. - Archs Zool. exp. gen. 70, 95-229.

Yasuzumi, G. \& Tanaka, H., 1958. Spermatogenesis in animals as revealed by electron microscopy. VI. Researches on the spermatozoon-dimorphism in a pond snail Cipangopaludina malleata. J. biophys. biochem. Cytol, 4, 621-632.

Yasuzumi, G., Nakano, S. \& Matsuzaki, W., 1962. Elektronenmikroskopische Untersuchungen über die Spermatogenese. XI. Uber die Spermiogenese der atypischen Spermatiden von Melania libertina Gould. - Z. Zellforsch. mikrosk. Anat. 57, 495-511. 